\title{
A CONCEPTUAL AND METHODOLOGICAL FRAMEWORK FOR EVALUATING R\&D PROJECTS
}

\author{
Giovanni Moura de Holanda \\ Centro de Tecnologia da Informação Renato Archer \\ giovanni.holanda@cti.gov.br \\ Claudio de Almeida Loural \\ Centro de Tecnologia da Informação Renato Archer \\ Carolina Vaghetti Mattos \\ Centro de Tecnologia da Informação Renato Archer \\ Angela Maria Alves \\ Centro de Tecnologia da Informação Renato Archer \\ angela.alves@cti.gov.br
}

\begin{abstract}
It is quite common the usage of generic terms in the description of Research \& Development (R\&D) projects and in the guidelines of public policies. Such an occurrence leads to polysemous or empty concepts, hampering the evaluation of policy and project results. In the field of innovation management, the terms "competitiveness" and "technological capacity building" are examples of such conceptual ambiguities. Moreover, some central objectives of incentive policies do not present directly measurable dimensions, being necessary the use of intermediate indicators to assess the impacts of such policies. This paper presents a reflection on the concept of these terms within the context of an incentive policy - the Brazilian Informatics Law -, and a methodological approach to evaluate these two attributes in R\&D projects that benefit from this law. In this effort, projects are categorized and positioned in a Quadrant Matrix, in accordance with their level of competitiveness and capacity building.
\end{abstract}

Keywords: Policy evaluation. R\&D projects. Evaluation methodology. Competitiveness. Technological capacity building.

\section{UMA MATRIZ CONCEITUAL E METODOLÓGICA PARA AVALIAR PROJETOS DE}

P\&D.

\section{Resumo}

É muito comum o uso de termos genéricos na descrição de projetos de Pesquisa e Desenvolvimento (P\&D) e nas diretrizes de políticas públicas. Tal ocorrência conduz a conceitos vazios ou polissêmicos, dificultando a avaliação de projetos e resultados de políticas. No campo da gestão da inovação, os termos "competitividade” $e$ "capacitação tecnológica" são exemplos dessas ambiguidades conceituais. Além disso, alguns objetivos centrais de políticas de incentivo não apresentam dimensões diretamente mensuráveis, sendo necessário o uso de indicadores intermediários para avaliar o impacto de tais políticas. Este artigo apresenta uma reflexão sobre os conceitos desses dois termos no contexto de uma política de incentivo - a Lei de Informática brasileira -, e uma abordagem metodológica para avaliar esses atributos em projetos de $P \& D$ que se beneficiam dessa lei. Nesse esforço, os projetos são categorizados e posicionados numa Matriz de Quadrantes, de acordo com seus níveis de competitividade e capacitação tecnológica.

Palavras-chave: Avaliação de políticas. Projetos de P\&D. Metodologia de avaliação. Competitividade. Capacitação tecnológica.

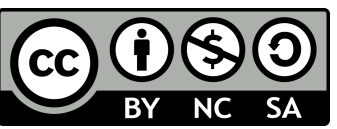

P2P \& INOVAÇÃO, Rio de Janeiro, v. 4 n. 1, p.147-168, Set./Fev. 2018. 


\section{Introduction}

Among the factors that define and are determinant to the whole process of evaluating the impacts of a project, or a policy, is the precise understanding of the objectives to be achieved and the choice of indicators that allow them to be evaluated. In addition to such factors, there is the need for a methodological approach that makes project or policy results evaluation possible in a comprehensive and contextualized way, yet observing the relationships between indicators.

In the description of R\&D projects and in the legal provisions governing public policies and their respective instruments, it is not unusual to find generic terms, whose usage is moreover widespread. As argued in (LOURAL et al., in press), it is presumed that this practice occurs as a way of reaching consensus among different social actors involved in the policy implementation.

There is a hazard, however, that the imprecise, improper or abusive use of these terms will lead to an emptying of the concept that underlies the justification of the policy or its instrument. It may generate a multiplicity of understanding that would undermine the policy's focus and jeopardize the achievement of desired objectives. In particular, for the evaluation of public policies, the precise conceptualization of the terms is fundamental in order to ensure the consistency of the process, from data collection to the choice of appropriate indicators $(c f$. Mattos et al., in press).

In the field of innovation management and policies, for example, the terms "competitiveness" and "technological capacity building" are often used in the context of R\&D and Innovation. An emblematic case is the Brazilian Law $N^{\circ} 8248 / 1991$, known as the "Informatics Law"1 (LOURAL et al., in press). The preamble to Law No 8248/1991 informs that it "provides for the capacity building and competitiveness of the informatics and automation sector, and provides other measures". Unfortunately, this concise and generic statement allow fluid interpretations of the real objective of this public policy instrument.

Moreover, considering further the case of the Informatics Law, some other expected objectives (such as the production chain density, competitiveness and technological capacity building) do not present tangibility neither directly measurable dimensions. For example, it is difficult to relate technological capacity ( $c f$. COOMBS \& BIERLY, 2006) to organizational

\footnotetext{
${ }^{1}$ Lei de Informática, in Portuguese.
} 
performance, or even isolating the effects of R\&D on traditional indicators, such as "revenues" and "export volume". Although there is a correlation between them, many endogenous factors, such as marketing and sales efforts, and exogenous factors - for instance exchange rate variation and macroeconomic and political conditions - directly interfere in the performance of companies and obliterate the effects of R\&D on the available indicators commonly used in evaluation processes.

In the absence of direct information on these factors, it is necessary to use intermediate measures (proxies) in order to evaluate the scope of the policy instruments designed under the Informatics Law. Thus, as presented in (HOLANDA et al., in press), an option is to use available indicators in a semi-qualitative approach, in order to evaluate the impacts arising from the Informatics Law. In this sense, projects are categorized and distributed in a qualitative evaluation matrix, composed of quadrants that map the relationship between competitiveness and capacity building - aspects associated with R\&D projects and expected objectives of that law.

This paper aims to work out the concepts of the terms "competitiveness" and "technological capacity building" within the context of the Informatics Law, as well as the analytical potential of the qualitative approach to evaluate these two attributes in R\&D projects associated to the requirements for using this law incentives. The conceptual and methodological framework thus constituted brings a double benefit: (i) to contribute to more comprehensive impact assessments of the policy instruments; and (ii) to enable the use of proxies to reveal causal relationships and interdependences between innovation/competitiveness and technological capacity building factors - characteristics that are hardly evident. In addition, one can perceive the potential of this semi-qualitative approach as an analytical support for R\&D and innovation projects in general, with application in the evaluation of policy instruments to encourage technological development.

\section{The conceptual imperative}

\subsection{Polysemy as an obstacle}

In the already mentioned preamble to the Informatics Law, the terms "capacity building" and "competitiveness" have generic meanings and suggest more induction of effects than quantitative and measurable results to be achieved. There is a fluidity of meaning in the 
use of the terms, without a clear concern with semantic rigor, for example aiming at future evaluations of results.

One may say that these words represent concepts with a certain portion of ambiguity: if, on the one hand, such malleability allows them to be adjusted to different approaches of measurement, on the other hand, this same characteristic compromises the accuracy of the intended evaluation. In general terms, in addition to the context of the Informatics Law, concepts such as "competitiveness" and "capacity building" do not present univocal, widely consecrated and uncontested definitions. It is also common to interpret terms such as competitiveness, innovation, and productivity in a confusing way, and even among economists and public managers ( $c f$. ATKISON, 2013).

\subsection{The concept of competitiveness}

Dictionary queries lead to the notion that competitive is the one that has the capacity to compete, whether in a sporting, professional or commercial environment. In the commercial and industrial context, one can understand "competitiveness" as the ability to face directly other people or firms competing for a given market, that is, to produce, distribute and provide goods and services in an environment in which other companies also do it.

However, this definition does little to understand what contributes to such capacity and even less to instruct an evaluation process of the effects of a policy instrument. According to Siudek and Zawojska (2014), the term "competitiveness", coined in the 70s, is employed in different contexts, meaning dissimilar things to different researchers.

Many works have sought to shed light on the understanding of the term competitiveness. A review of the literature on the evolution of this concept is presented in (ANCA, 2012), including different perspectives and reflecting under various economic theories. On the divergence of understandings, the author states that the "lack of a clear unanimously accepted definition represents a source of constant controversy, the main argument being that it is quite dangerous to construct an economic policy around such an amorphous and interpretable concept".

Nevertheless, during the 1980s, Michael Porter's approach to competition in markets and between nations was very influential. Porter's basic idea, by the way still useful for formulating business strategies, was that five major forces influenced the level of competition in a given market (PORTER, 1979). 
- The capacity of companies to deal with the rivalry of current competitors

- The threat of new entrants to the market;

- The threat of new products (or services) that may replace the one that is the focus of the market;

- The bargaining power of suppliers; and

- The bargaining power of customers.

Of the "five forces," the first three in the order presented here directly relate to competing firms. As argued initially by these authors (LOURAL et al., in press), the ability to deal with current competition, for example, depends heavily on cost and marketing strategies, differentiation of products, and so on. The ability to face new competitors entering the market also depends on how the company uses the various resources of its strategic arsenal.

With regard to the differentiation of products, the importance of the technological dimension is evident. The existence in the company of a culture focused on technological innovation and constant development of new products and processes leads to an advantageous position to face the current competition and the new entrants, as well as, with much more reason, to face the threat of new products or services that can replace the market object.

From this work on competitive forces, Porter continued to elaborate his approach to business strategy during the 1980s, disseminating it and consolidating the term "competitive advantage" through articles and works that gained much popularity (such as the book Competitive Advantage, 1985). Next, Porter (1990) extended the concept of corporate competitiveness to the countries themselves. In that article, he points out that the competitiveness of a nation depends on the capacity of its industry to innovate and progress.

Reinert (1995) has done a review work on the evolution of the concept of "competitiveness" that is very relevant to the present reflection. According to him, OECD (Organization for Economic Co-operation and Development) conceptualized "competitiveness" in 1992 in terms of international acceptance of company's goods and services under open market conditions. This concept, therefore, also carries the idea that competitiveness would not be equivalent to productivity, but would generate economic advantages that would benefit the country and its population as a whole.

Reinert shows in his paper how the role of technical change, the aggregation of manufacturing value over the extraction of raw materials and some protection at the national level were already perceived since before the classic economic formulations, continuing 
vivaciously during the nineteenth century. While Adam Smith and David Ricardo saw a scenario of perfect competition in relatively stable markets in which comparative advantages are a success factor, the other perception understood the market as dynamic and imperfect and sought to extract advantages from it, through active measures. In Schumpeter, in the first half of the 20th Century (with Capitalism, Socialism and Democracy, 1942), the idea of "creative destruction" reinforced the economic question behind the concept of "competitiveness": in a dynamic market competition is clearly imperfect. In this context, advantage is on the side of those actors capable to innovate, or to offer products and services with elements of novelty that highlight their differences in relation to those of the other competitors.

In a very different vision of these ones, in a challenging counterpoint to the market in expanding globalization of the 1990s, Krugman (1994) concludes his controversial article with the following words: “... competitiveness is a meaningless word when applied to national economies. And the obsession with competitiveness is both wrong and dangerous". In addition to reinforcing the lack of meaning for the term competitiveness, this author believes that the competitiveness metaphor is used as justification for national policies rather than as a synonym for products with a truly competitive differential.

In any case, the "competitive advantage", as conceived by Porter, can be considered simply as the expression of a power or ability to succeed in a scenario of imperfect competition in dynamic markets. Using Porter's language, it would not be enough to compete only for the reduction of costs, but mainly for some kind of differentiation that would allow the country to appropriate of the economic advantage deriving from that differentiation.

\subsection{Competitiveness and technological innovation}

Reinert, in his work previously mentioned (1995), relates some factors that characterize the economic activities of "high quality", another way of designating the activities that constitute the dynamic markets, where imperfect competition is present: innovative trajectories, windows of opportunity, high R\&D contents, learning by doing, qualified personnel, high barriers to entry, industrial concentration, importance of brands, among others.

By economic prism, therefore, the role of technology in the composition of "competitiveness" emerges naturally. The theoretical framework consolidated after Schumpeter - see, for example, (HADDAD, 2010) - understands technological innovation as fundamental to the success of a company (or country) operating in dynamic markets. This leads 
to envisage the technological dimension of competitiveness or, simply, the "technological competitiveness".

The Information and Communication Technology (ICT) market is a clear example of dynamic market, of Schumpeterian market. The policy commenced in Brazil by the instrument of the Informatics Law (as ICT was still understood in the last decades of the last century) was a policy that sought to encourage national companies to become competitive in a rather imperfect market and, consequently, to bring socio-economic benefits for the country.

Law $\mathrm{N}^{\circ} 8248 / 91$ does not address the competitiveness of the sector in terms of marketing, sales channels or even business management processes. If there is an economicfinancialdimension, configured in the reduction of IPI, there is a corresponding requirement of production in the country and of resource application in $R \& D$ projects. It is evident the focus on technological competitiveness.

\subsection{The concept of technological capacity building}

In Decree $n^{\circ} 5906 / 2006$ (BRASIL, 2006), instrument associated to Law $N^{\circ} 8248$, the term "capacity building" sometimes appears. In its article 32 , the meaning of the term refers to "instruction" or "learning", relating to the subject of human resources for the area. In article 24, there is mention of the concepts of "instruction and capacity building", making it clear that the focus is on aspects of professional preparation of human resources. However, the wording is so broad, so open, that it is difficult to distinguish what is and what is not acceptable when analyzing R\&D project or evaluating an ICT policy.

This Decree explicitly accepted training activities (instruction) as R\&D, even when they are not related to the object of the R\&D activity (section IV "a" and "c"). Nevertheless, by requiring the company to perform $\mathrm{R} \& \mathrm{D}$ project as a counterpart, the law also creates an expectation of result that is scientific and technological in nature, even for the sake of a conceptual consistency of the very policy.

While research and development are concepts with international foundation in reference documents, accepted and adopted by the Brazilian government, this does not happen with professional training and capacity building. These terms, on the contrary, belong to a domain other than R\&D. Besides, no reference documents, equivalent to the Frascati Manual (OECD, 2002), have been found. 
That Handbook does not recognize education and training per se as R\&D activities (pp. 30-34). However, according to this same reference text, education and training expenses can be considered as $R \& D$ expenses if such expenses are incurred in projects recognized as R\&D.

Usually dictionaries and conventional terminologies define capacity building as "the act or effect of being capacitated"; habilitation, aptitude. The adjective "professional" introduces a more restrictive context, aimed at the exercise of a profession. Dictionaries also uses the term "capacity building" or the verb "to capacitate" in the sense of preparing for the job market.

Some authors - (FERRETTI, 1997), (MATOS \& ARRUDA, 2012), (ANTUNES et al., 2001) - corroborate the conclusion that professional capacity building can be defined as the habilitation of the individual to perform a specific task, function or activity through appropriate knowledge and attitudes. In turn, the scope of professional education would be broader and deeper, a set of activities aimed at acquiring knowledge, skills, attitudes and behaviors required for the exercise of the functions proper to a profession or group of professions in any segment of economic activity.

Thus, capacitation and education would be two forms of professional preparation, one more immediate and practical, the other broader and deeper. In this sense, when article 24 of Decree $N^{\circ} 5906$ provides on capacity building, it seems to be restricted to this aspect of professional preparation.

The reading of the term "capacity building" is very useful from a practical, operational point of view, to carry out a project analysis and also to the quantitative measurement of human resources formed in the ICT area under the "Information Technology Law" instrument. However, with this restricted use, another aspect of learning is obscured, especially in the technological domain: the management of knowledge learning, with the consequent strengthening of the technological competencies of companies or organizations.

Figueiredo (2006) offers an interesting analysis of the question and brings some relevant points to the present work. The author uses the expression "technological capability" in the sense of learning technologies ${ }^{2}$. His approach follows the notion of "assimilation", a concept that emphasizes the role of accumulation of knowledge, through learning processes, for the implementation of innovation strategies aimed at accelerating economic growth.

\footnotetext{
${ }^{2}$ In order to deepen the understanding of the concept of technological capability, Reichert et alii (2012), for example, present a compendium of definitions of technological capability, and a review of the literature on this theme is found in (GUERRA\& CAMARGO, 2016).
} 
Figueiredo also proposes a metric to evaluate technological capabilities in ICT organizations, structured in six levels, from basic to advance. What emerges from this classificatory scale is the growth in complexity and sophistication of the organization's capability. One can observe the strong role that the most advanced levels require in terms of knowledge accumulated inthe organization.

This author focused his research on R\&D organizations in the Brazilian ICT area, with emphasis in software development, but not only. The sources of technology of these organizations were quite varied, ranged from hiring specialized human resources to research contracts, and including different ways of acquiring knowledge. However, he admits that a limitation of his study was to have not explored the relationship between the sources of knowledge employed and the level of technological capability of the organizations.

It is exactly at this point that the present article adds a contribution. The process of moving from the most basic levels to the most advanced levels of "technological capability" can be considered as a process of "technological capacity building" - an extension of the restricted concept of professional capacity building of individuals to the strategic capacity building of organizations. Therefore, "technological capacity building" can be understood as a process of learning, accumulation and assimilation of knowledge, which is larger as the technology source belongs more and more to the organization, not to external sources.

Pake (1986) aligns seven reasons for a company to invest in research. Among them, we highlight two, which have special affinity with the line of "capacity building" addressed in more depth in this article: to develop new research and engineering tools; and build a base of knowledge and skills.

Although made 30 years ago, Pake's argument is still quite contemporary, especially in the area of ICT. Regardless of the volume of resources and the diversity of application areas, $\mathrm{R} \& \mathrm{D}$ is a process of acquiring and accumulating technological knowledge (the technological capacity building) by which companies construct an asset (technological capability) that, duly assimilated by the organization, allows it will compete in the market in a more advantageous position.

In this line of developing the internal market, some actors interpret technological capacity as a way to achieve technological endogenization and consequently for the country's technological autonomy - $c f$. (CABRAL, 2012) and (DEITOS, 2012) - or that investments in S\&T allow for competitive prices and economic and industrial development for the country itself. 
We thus see an interesting perspective on the meaning of the term "capacity building", denoted by a bidirectional causal relationship between capacity building and competitiveness. Specifically on such possibility, in the 90's Furtado et alii (1994) already remarked that the relationship between technological capacity building and competitiveness should not be addressed univocally.

Therefore, to deepen this reflection a little more, it is quite reasonable to understand the R\&D process also as a form of capacity building: the management of the knowledge acquired and assimilated directly by investigative practices carried out in a company. In another way, R\&D activity in its strict meaning (for example, following the concepts of the Frascati Manual) corresponds to a process of acquisition and accumulation of technological knowledge. The accumulation of this knowledge contributes to the building of intangible competencies necessary to achieve the desired results by an organization that uses R \& D activities to strengthen it. These strategic results include competitive advantage in the markets in which it competes.

In formulating the concise preamble to Law $\mathrm{N}^{\circ} 8248 / 91$, the legislator may have unconsciously created a binomial that reflects the essence of what is expected of $R \& D$ investment by companies and, consequently, of the country itself: a process of R\&D as a form of technological capacity building that results in innovations that contribute to market competitiveness.

\subsection{Applying the concepts of competitiveness and capacity building}

By focusing on the technological dimension of competitiveness and capacity building, a link is naturally established between them and the company's R\&D activities and projects. An analysis or measurement of the results of the Informatics Law would then seek to verify among other aspects how or how much R\&D projects carried out under the stimulus of the Law contribute to the competitiveness and technological capacity building of the company

However, it is difficult to extract the precise effective contribution of $R \& D$ projects to the company's revenue, profit or some other economic or financial indicator. Nor is it immediate to isolate the $\mathrm{R} \& \mathrm{D}$ contribution to some clearly technical indicator such as "number of new products".

In the case of evaluating projects developed under the scope of the Law $\mathrm{N}^{\circ} 8248 / 91$, it is possible to construct a path, a relationship, a link between the "competitiveness" objective, 
expressed at a high level in the preamble of the Law, and the requirement of technological innovation associated to such an objective. This requirement is also expressed in article 24 of Decree 5906/2006 that regulates the Informatics Law.

Similarly, it is also possible to establish a relationship between the objective of "technological capacity building" expressed in the Law and, on the one hand, the quantitative measurement of human resources trained in ICT and, on the other hand, the acquisition of knowledge about the very $R \& D$ process. With this last understanding about the term "capacity building" indicating the maturity of R\&D processes - leverage for technological autonomy and construction of competitive differential.

The path thus traced consists of:

- Evaluating whether the results of a project executed as a counterpart to the benefits of the Informatics Law bring a technological innovation, completely or in part. To put it another way, evaluating if there is an element of novelty in the project results that represents a significant differentiation factor, in such a manner that allows the company to compete in the market in a more advantageous position than its competitors.

- Evaluating also if the results of the project were obtained from a systematic work, applying and developing scientific knowledge, in order to contribute to the company's capacity building and to the maturity of the very $R \& D$ process.

- Appropriating advantages obtained, identified by the two evaluation branches described above, in order to contribute to a better economic and financial performance of the company and, consequently, the country.

The links thus constructed find support in the conceptual framework herein presented. This framework was applied to lay the foundation of project evaluation criteria in structured methodologies, serving as axes of a support tool for project analysis named "Quadrant Matrix", described as follows.

\section{A semi-qualitative approach to analysis}

As mentioned in the introduction to this paper, some central objectives expected for the Informatics Law, such as the increase of the production chain density, competitiveness and technological capacity building, do not present directly measured tangibility or dimensionality. An option to surpass this limitation is the use of intermediate measures (proxies) so that it is 
possible to evaluate the reach of the policy instruments with respect to the central objectives expected of the law.

Thus, this approach was adopted to analyze the results of the evaluation of $R \& D$ projects, carried out based on the specific methodology of the AvalRDA Project ${ }^{3}$, by means of a semi- qualitative approach, in order to composing a more elucidative picture about the impacts arising from the Informatics Law. In such an approach, the projects encouraged by the incentives of Informatics Law are the basic unit of analysis, classified according to the criteria and gradation in levels specified in the AvalRDA methodology, submitting them to a qualitative analysis in terms of the objectives set by the incentive policy - hence the semiqualitative designation.

The categorization of projects according to these criteria and levels is distributed in a qualitative evaluation matrix, composed of quadrants that map the relationship between competitiveness and capacity building, or more specifically between the factors Technological Advance and Development Process. These are conditioning factors of the "competitivenesscapacity building" binomial, which express the expected objectives of the Informatics Law and are associated with $R \& D$ projects. Therefore, the matrix designed for such purpose is here termed the Quadrant Matrix AT x PD (in allusion to the acronym in Portuguese formed from these two factors), as presented from a perspective of analytical potential in (HOLANDA et al., in press).

\subsection{Dimensions of the AT x PD Matrix}

As shown in Figure 1, the vertical line of the matrix represents the potential gain of competitiveness made possible by the technological advancement. Competitive advantages can be achieved by differentiation resulting from innovation ( $c f$. PORTER, 1985); or by the domain of technological competencies that allow to innovate ( $c f$. PRAHALAD \& HAMEL, 1990). In this manner, the projects are evaluated in terms of competitiveness, verifying the presence of elements of novelty that result in technological advancement.

The horizontal line of the matrix, in turn, corresponds to the potential gains of learning and capacity building, which result from the execution of the development process. From this angle, the carrying out of $R \& D$ projects is considered in terms of technological capability (cf.

${ }^{3}$ A methodology for evaluating R\&D projects under the Informatics Law's scope (CTI/FACTI, 2015). 
FIGUEIREDO, 2006) and of the technological learning process (cf. KOCOGLU et al., 2012). Thus, the dimensional composition of the matrix can be summarized in a relation between process and its outputs, in which the horizontal line of the matrix is associated to processes, and the vertical line, to results.

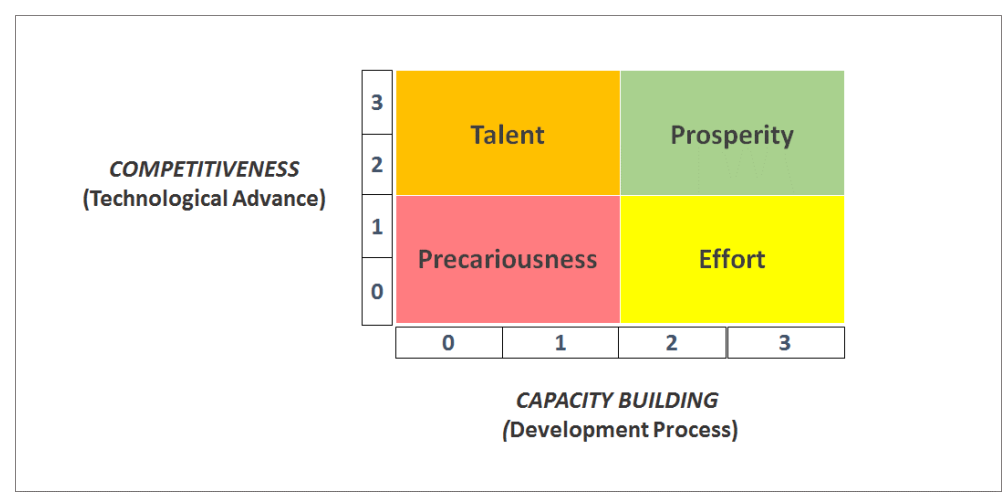

Figure 1: Dimensions of the AT x PD Matrix

Source: adapted from (HOLANDA et al., in press)

In the characterization of $R \& D$, investigative activities have the final purpose of finding alternatives to solve problems whose solutions are not necessarily known. Such activities are naturally interwoven with the "elements of novelty" that promote "technological advances", from the unfolding of processes as described as follows.

\subsection{Investigative activity in $R \& D$ projects}

The previous methodological developments - carried out in the institutional context in which this work is inserted - led to conceptualize R\&D as an activity performed in a systematic, investigative and experimental way. In objective terms, one can summarize these performing modes with the following characteristics:

- A systematic activity avoids the purely empirical and disordered creation of solutions; formulates and tests hypotheses; analyzes errors and failures in light of scientific principles; understands the whys; and corrects hypotheses and procedures;

- An investigative activity seeks answers to problems whose solution is not immediate, is not obtained with the stock of knowledge already available; requires new knowledge, since existing ones are not enough to achieve the solution. 
- An experimental activity tests and validates hypotheses and knowledge before they are used in a regular way, that is, incorporated into the stock of knowledge of the professionals of the area.

The R\&D Project evaluation methodology (originally developed and later adapted to the context of the Informatics Law) sought to combine the investigative and experimental aspects in a single criterion. This is because the "experimental" activity corresponds to tests and validations to justify - by means of investigation procedures - the response with which the $\mathrm{R} \& \mathrm{D}$ project is trying to solve the proposed problem. In $\mathrm{R} \& \mathrm{D}$ projects, the answer corresponds to the resolution of a scientific or technological uncertainty.

Such an uncertainty exists because the solution of the problem is not readily apparent to someone familiar with the basic stock of knowledge and usual techniques in that area of interest. That is, there is a natural enchainment from the problem or challenge posed to the project up to its outcome. Such an enchainment represents ultimately the contribution of the project to the technological capacity building or, more fully, the learning of the team that carry it.

In addition, "investigative activities" and "elements of novelty" (and the "technological advances" resulting from such elements of novelty) are naturally linked. The notion of "novelty element" is associated with knowledge, techniques or practices that are not common knowledge for professionals in the area of interest, which is another way of speaking about scientific and technological uncertainties that demand "investigative activities".

Even in projects that tend to be much more conducive to development than to research, the concepts of product, device, system or process go through a sequence of steps that necessarily include the proof and validation of the concepts ("investigative activities" plus "experimental activities") to be incorporated into the ultimate result of a project. This idea was very well synthesized by Roussel et alii (1992).

In summary, the existence of investigative activities is an essential characteristic in $\mathrm{R} \& \mathrm{D}$ projects, as far as learning and capacity building processes are concerned. Here again a direct relationship between $R \& D$, technological capacity building and competitive differential arises; the latter is achieved from technological advances, according to the meaning given to the concept of capacity building.

\subsection{Mapping projects in the AT $x$ PD Matrix}


Regarding the positioning of the projects in the matrix, a project that, according to the application of the AvalRDA methodology, received high grades in the criterion "technological advance" tends to be a project that presents some element of novelty (new knowledge, materials, products, processes, etc., or significant improvements), thus attributing more competitiveness to the company.

In terms of the development process, a project that has high marks in the criterion "investigative activities" tends to be a project with good $R \& D$ process, since it has contemplated stages of experimentation, evaluation, verification and validation, showing that it complies with the principles of the scientific method and contributes to learning and capability building. Projects with low marks in this criterion, even if they have been well structured and contextualized, reveal a more incipient R\&D process, given that the working hypotheses did not completely go through the steps above-mentioned.

In Figure 2, the gradation at four levels or degrees attributed to these two criteria is illustrated. In the vertical plane, the levels associated with "technological advance" cover from the case in which there is no demonstration of results until the case in which it is possible to perceive the expansion of knowledge by explicit comparison. In the horizontal plane, the levels related to "investigative activities" vary from a situation with no indication of this activity until a situation with description and results of sophisticated tests for confirmation (evidence of proof).

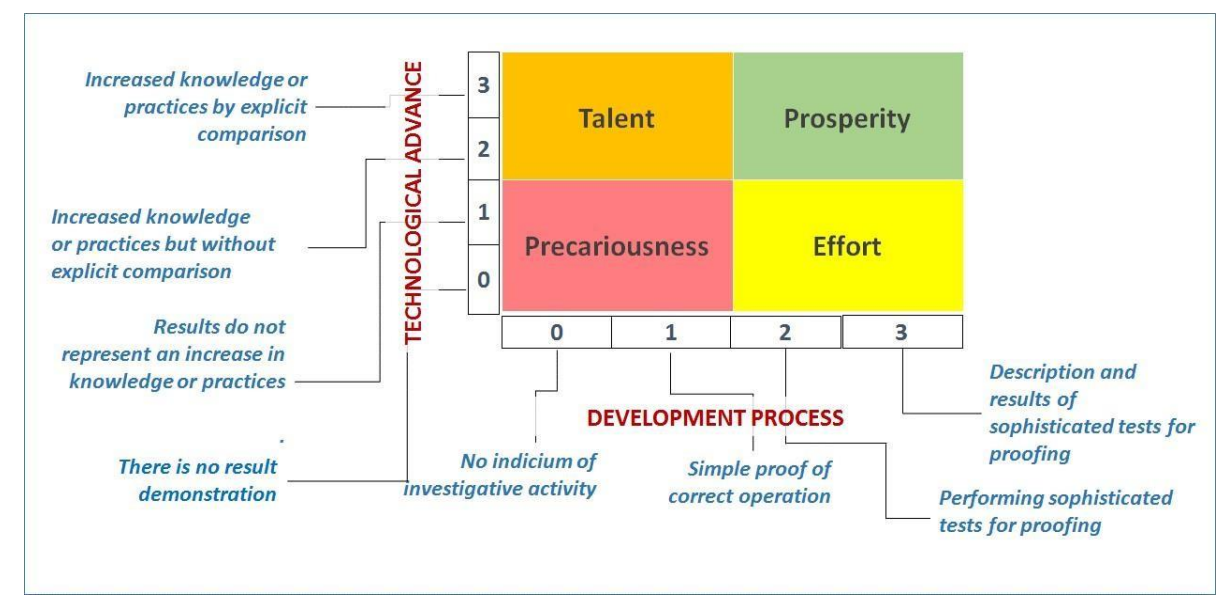

Figure 2: Gradation for project positioning in the AT x PD Matrix Source: adapted from (HOLANDA et al., in press)

For ease of treatment and quick visualization, the matrix was divided into four parts or quadrants: 
- The green quadrant (top right) brings together the most innovative and investigative projects with high marks ( 2 or 3 on a scale ranging from 0 to 3 ) in both the "investigative activities" criterion and the "technological advance" criterion. In the light of the Informatics Law, they would be, in principle, the projects that could best represent the achievement of its objectives. Metaphorically, one can say that these projects denote a condition of prosperity for the companies that realize them;

- The yellow quadrant (bottom right) includes projects with a good development process (high marks, 2 or 3, in the criterion "investigative activities"), but little or no technological advance (low marks, 0 or 1, in the criterion "technological advance"). The positioning in this quadrant can mean that the project is inserted in an organizational context that is committed to the process of learning and capacity building, through investigative or experimental activities, however with results that are not elements of novelty or of technological advance. Based on a metaphorical resource, it can be said that they are projects performed by companies that employ investigative effort without, however, being able to innovate or obtain competitive differentials;

- The orange quadrant (top left) includes projects with poorly explained developmental process (low marks, 0 or 1, in the criterion "investigative activities"), but leading to technological advances (high marks, 2 or 3, in the criterion "technological advance") and competitiveness. It can mean that the project is inserted in organizational contexts of strong market orientation, without, however, prioritizing the investigative or experimental processes. Metaphorically, it can be conjectured that these projects primarily reflect inspiration and talent predicates - the natural craft ability attributed to the companies that lead them -, to the detriment of systematic research efforts and experimental proof of the assumptions and premises that led to such a development. It may also be a consequence of the absence of scientific culture or methodological rigor, or even an indication of little "interest" in expressing how the work was performed. 
- The red quadrant (bottom left) includes projects with routinely or poorly explained developmental processes (low marks, 0 or 1 , in the criterion "investigative activities"), and with little or no technological advance (low marks, 0 or 1, in the criterion "technological advance"). Metaphorically, these projects are characterized by precariousness in the face of the objectives of promoting competitiveness, learning and capacity building of companies in ICT area.

\section{Final remarks and perspectives}

In the reflections on the concept of "competitiveness" and "technological capacity building", it was possible to establish a reasoned link between them, regarding the methodologies of project analysis and the support tools that have been developed.

The objective of "capacity building" expressed in the legislation and regulations of the Informatics Law carries both the meaning of professional preparation and the implicit sense of acquisition and accumulation of technological knowledge. This implicit meaning is very useful in evaluating projects of the beneficiary companies, since it can be associated with the R\&D process itself.

The link thus constructed finds support in the conceptual framework that was presented in this paper, although briefly due to the limitations of space. It was applied as a rationale for explaining the project evaluation criteria in structured methodologies, and served as one of the axes of the project analysis tool denominated Quadrant Matrix, which was conceived to analyze competitiveness and technological capacity building in R\&D projects aimed at ICT.

One of the applications made possible by the analytical potential of the AT x PD Matrix is to provide a picture of the evaluated $R \& D$ projects, in terms of the employed efforts and achieved results. Such a framework may serve as a basis for the establishment of action plans aimed at promoting upward mobility between quadrants. This means that over time, more and more projects fomented by a policy instrument such as the Informatics Law can be classified into quadrants corresponding to higher marks, with the perspective of greater benefit for the companies that execute them. These plans may contain strategies for gradual mobility or be focused on impelling future projects directly into the condition of prosperity, according to company's business planning and the sectoral policy in force.

Concerning gradual mobility, the plans may aim at, for example, the transition from a situation of precariousness to a condition of talent or effort, in accordance with the matrix 
methodological approach and taking into account the objectives of the projects and the strategies envisaged by the companies. Otherwise, plans can bring together actions to encourage the creation of elements of innovation and thus promote the transition from a condition of effort to a condition of prosperity. Alternatively, companies whose projects reflect the predicates of talent can establish plans that strengthen research activities in their future projects, aiming to combine development and capacity building with innovation and technological competitiveness. Finally, the framework provided by the matrix could behave as an organizational planning tool, supporting the formulation of plans to promote the rise of projects to a condition of contributing to the company's prosperity, in a path favorable to the sustainable technological development.

Another possible application is to serve not only as an instrument for evaluating projects and their impacts, but also as a reference for designing new science, technology and innovation policies. Thus, in addition to enabling mobility plans for projects and adjustments in policy instruments already in progress, the application of the AT x PD Matrix provides analytical inputs for the promotion of new policies that contribute to the promotion of competitiveness and capacity building in sectors or technologies that are the subject of a policy. By proposing an incentive policy design, it is possible, for example, to require that the projects to be contemplated present detailed description of the research planning and the demonstration, by explicit comparison, of the increase of knowledge or practices that the projects are intended to achieve. There is also the possibility of defining clues and/or evidences to prove compliance with such requirements. Yet, for each technology or industry, a set of requirements can be specified for each of the axes or quadrants. In this way, it is possible to make available a roadmap of good practices that contribute to achieve better project results, as well as elements to provide metrics most appropriate for evaluating the policy in question.

In conclusion, this paper presented a conceptual framework and a semi-qualitative methodological approach for the classification of $R \& D$ projects executed within the context of the Informatics Law. The use of these elements to support project analysis is suitable enough both for companies benefiting from incentives and for policy makers that formulate, decide and monitor public policies. In addition, the authors of this work believe that this approach can be used in other contexts, as an analytical support for R\&D and innovation projects, with application in the evaluation of policy instruments to encourage technological development. 
For the continuity and deepening of the conceptual and methodological framework introduced herein, as well as to extend its application in R\&D projects under other policies, some points are being worked out:

- Expand the understanding of "competitiveness" by including the concepts of "cooperation" and "sharing" - for example, as proposed in (ALVES, 2013) -, in the sense of collaboration and maximization of efforts to achieve common goals.

- Promote the mobility of the very Quadrant Matrix, expanding the concepts of "competitiveness" and "technological capacity building", and intensifying the link between them as a two-way causal relation. Such an intensification may evolve up to the point of conceiving these two concepts as interwoven and inseparable parts of the same R\&D activity.

\section{Acknowledgments}

The authors are grateful to the Brazilian National Council for Scientific and Technological Development (CNPq) for the support, in the form of institutional capacitation scholarships, which allowed this work to be carried out.

\section{REFERENCES}

ALVES, A.M. Proposal of a measurement structure for quality of SPB Brazilian Public Software (In Portuguese). PhD Thesis - Polytechnic School, University of São Paulo, 2013. Available at:

<http://dx.doi.org/10.11606/T.3.2013.tde-11072014-001021>.

ANCA, H.D.B. Literature review of the evolution of competitiveness concept. The Journal of the Faculty of Economics, University of Oradea, v. 1, n. 1, p. 41-46, 2012.

ANTUNES, A.; CAMPOS, M.; SILVIA, M.; SOUSA, M. Terminologia de formação profissional. Lisboa: DGEFP, 2001. 
ATKISON, R.D. Competitiveness, innovation and productivity: clearing up the confusion. The Information Technology \& Innovation Foundation, 2013. Available at: <www2.itif.org/2013-competitiveness-innovation-productivity-clearing-up-confusion.pdf > . Access on: 15may2017.

BRASIL - Presidência da República, Casa Civil. Lei no 8.248, 23/10/1991.

BRASIL - Presidência da República, Casa Civil. Decreto nº 5.906, 26/09/2006.

CABRAL, A.C. The Constitution and the ways toward a technological autonomy: an approach between structuralists and evolutionists (In Portuguese). Revista da Faculdade Mineira de Direito, v. 15, n. 30, 2012.

COOMBS, J.E. \& BIERLY, P.E. Measuring technological capability and performance. R\&D Management, v. 36, n. 4, p. 421-438, 2006.

CTI/FACTI. Metodologia específica para a análise do legado de 1900 RDA a partir do ano-base de 2006, versão 1.1, 2015. Available at:

$<$ http://sigplani.mct.gov.br/arquivos/

MetAnalise1900.pdf>. Access on: 15 may 2017.

DEITOS, M.L.M.S. The process of technology incorporation in Brazilian industry: from the beginnings of industrialization to the trade liberalization in the 1990s (In Portuguese). Revista Gestão \& Tecnologia, v. 12, n. 1, p. 04-25, 2012.

FERRETTI, C.J. Formação profissional e reforma do ensino técnico no Brasil: anos 90. Educação \& Sociedade, v. XVIII, n. 59, p. 225-269, 1997.

FIGUEIREDO, P. N. Capacidade tecnológica e inovação em organizações de serviços intensivos em conhecimento: evidências de institutos de pesquisa em Tecnologias da Informação e da Comunicação (TICs) no Brasil. Revista Brasileira de Inovação, v. 5, n. 2, 2006.

FURTADO, A. (coord.). Capacitação tecnológica, competitividade e política industrial: uma abordagem setorial e por empresas líderes. Texto para discussão $\mathrm{n}^{\circ} 348$. Brasília: IPEA, 1994. Available at: 〈http://www.ipea.gov.br/portal/images/stories/PDFs/TDs/td_0348.pdf〉. Access on: 4may2017.

GUERRA, R. M. A. \& CAMARGO, M. E. The role of technological capability in the internationalization of the company and new product success: a systematic literature review.

Internext - Revista Eletrônica de Negócios Internacionais, v. 11, n. 1, p. 49-62, 2016.

HADDAD, E.W. Inovação tecnológica em Schumpeter e na ótica neo-schumpeteriana. Trabalho de Conclusão de Curso em Ciências Econômicas. Porto Alegre: UFRGS, 2010. Available at: 〈www.lume.ufrgs.br/handle/10183/25385>. Access on: 4may2017.

HOLANDA, G.M., MATTOS, C.V., LOURAL, C.A., \& ALVES, A.M. Matriz de quadrantes 
para análise de competividade e capacitação tecnológicas em projetos de P\&D. In: VIII Seminário em TI do PCI/CTI, Campinas -SP, 2017. Anais..., Campinas -SP, in press. (Prevision Screen - 2nd Semester of 2017)

KOCOGLU, I.; IMAMOGLU, S. Z.; INCE, H.; KESKIN, H. Learning, R\&D and manufacturing capabilities as determinants of technological learning: enhancing innovation and firm performance. Procedia - Social and Behavioral Sciences, v. 58, p. 842-852, 2012.

KRUGMAN, P. Competitiveness: a dangerous obsession. Foreign Affairs, v. 73, n. 2, p. 2844, 1994.

LOURAL, C.A.; MATTOS, C.V.; HOLANDA, G.M. \& ALVES, A.M. O conceito de "competitividade" e sua aplicação no contexto de avaliação de políticas públicas: o caso da Lei de Informática. In: VIII Seminário em TI do PCI/CTI, Campinas -SP, 2017. Anais..., Campinas -SP, in press. (Prevision Screen 2nd Semester of 2017)

MATOS, O.A. \& ARRUDA S.R. Metodologia SENAI para formação profissional com base em competências: um estudo de caso sobre a implantação deste método no Departamento Regional do SENAI de Santa Catarina. E-Tech: Tecnologias para Competitividade Industrial, n. Especial - Educação, p. 34$58,2012$.

MATTOS, C.V.; LOURAL, C.A.; HOLANDA, G.M. \& ALVES, A.M. O conceito de "capacitação" e a Lei de Informática. In: VIII Seminário em TI do PCI/CTI, Campinas -SP, 2017. Anais..., Campinas -SP, in press. (Prevision Screen - 2nd Semester of 2017)

OECD. Frascati Manual - Proposed standard practice for surveys on research and experimental development. Paris: OECD, 6th edition, 2002.

PAKE, G.E. Business payoff from basic science at Xerox. Research-Technology Management, v. 29, p. 35-40, 1986.

PORTER, M. E. How competitive forces shape strategy. Harvard Business Review, v. 57, n. 2, p. 137-145, 1979.

. Competitive Advantage. Free Press: New York, 1985.

. The Competitive Advantage of Nations. Harvard

Business Review, v. 68, n.2, p. 73-93, 1990.

PRAHALAD, C.K. \& HAMEL, G. The Core Competence of the Corporation. Harvard Business Review, v. 68, n. 3, p. 79-91, 1990.

REICHERT, F. M.; ZAWISLAK, P. A.; PUFAL, N. A. Os 4Ps da Capacidade Tecnológica - uma análise de indicadores de medição. In: XXVII Simpósio de 
Q INOVAÇÃo

Gestão da Inovação Tecnológica, Salvador - BA, 2012. Anais..., Salvador - BA, 2012.

REINERT, E.S. El Concepto “Competitividad” y sus Predecesores. Socialismo Y Participación, v. 72, p. 21-40, 1995.

ROUSSEL, P., SAAD, K. \& BOHLIN, N. Pesquisa e Desenvolvimento como integrar P\&D ao Plano Estratégico e Operacional das Empresas como Fator de Produtividade e Competitividade. São Paulo: Makron Books, 1992.

SCHUMPETER, J. A. Capitalism, socialism and democracy. Harper \& Brothers Books, $1^{\text {st }}$ ed., 1942.

SIUDEK, T.; ZAWOJSKA, A. Competitiveness in the economic concepts, theories and empirical research. ACTA Scientiarum Polonorum. Oeconomia, v.13, n.1, 91-108, 2014. 